Original Research Paper

\title{
Pelatihan Pengelolaan Sampah Sisa Makanan Restoran Apung Berbasis Agen Biologi Black Soldier Fly (BSF)
}

\author{
Fariz Primadi Hirsan ${ }^{1}$, Ibrahim $^{2}$, Salikin $^{3,4}$, Mursal Ghazali ${ }^{5}$, Nurhayati ${ }^{6 *}$ \\ ${ }^{1}$ Program Studi Perencanaan Wilayah dan Kota, Fakultas Teknik, Universitas Muhammadiyah Mataram, \\ Mataram, Indonesia \\ ${ }^{2}$ Program Studi Geografi, Fakultas Keguruan dan Ilmu Pendidikan, Universitas Muhammadiyah Mataram, \\ Mataram, Indonesia \\ ${ }^{3}$ Rumah Magot Lombok, Lombok Barat, Indonesia \\ ${ }^{4}$ UPTD Laboratorium Lingkungan, Dinas Lingkungan Hidup Kota Mataram, Mataram, Indonesia \\ ${ }^{5}$ Program Studi Biologi, Fakultas Matematika dan Ilmu Pengetahuan Alam, Universitas Mataram, Mataram, \\ Indonesia \\ ${ }^{6}$ Program Studi Teknologi Hasil Pertanian, Fakutas Pertanian, Universitas Muhammadiyah Mataram,Mataram, \\ Indonesia
}

https://doi.org/10.29303/jpmpi.v3i2.979

Sitasi: Hirsan, F. P., Ibrahim., Salikin, Ghazali, M \& Nurhayati. (2021). Pelatihan Pengelolaan Sampah Sisa Makanan Restoran Apung Berbasis Agen Biologi Black Soldier Fly (BSF). Jurnal Pengabdian Magister Pendidikan IPA, 4(3)

\author{
Article history \\ Received: 31 Agustus 2021 \\ Revised: 19 September 2021 \\ Accepted: 21 September 2021 \\ *Corresponding Author: Nurhayati, \\ Program Studi Teknologi Hasil \\ Pertanian, Fakutas Pertanian, \\ Universitas Muhammadiyah \\ Mataram, Mataram, Indonesia \\ Email: \\ nurhayati.faperta.ummat@gmail.com
}

\section{Pendahuluan}

Sampah merupakan material yang dibuang sebagai sisa dari hasil produksi industri maupun rumah tangga. Definisi lain dari sampah adalah benda-benda yang sudah

\begin{abstract}
Sampah merupakan material yang dibuang sebagai sisa dari hasil produksi industri maupun rumah tangga. Sebagian besar sampah yang dihasilkan merupakan sampah organic. Salah satu yang wilayah yang menghasilkan sampah dalam jumlah besar adalah wilayah yang dijadikan sebagai daerah tujuan wisata. Salah satunya adalah desa Ekas Buana. Desa ini menjadi tujuan wisata bebasis keindahan pantai dan wisata kuliner restoran apung. Peluang munculnya permasalahan di laut akibat makanan dan minyak goreng sisa sangat besar. Oleh sebab itu, dilakukan antisipasi dengan melakukan sosialisasi dan pelatihan pengelolaan sampah organic berbasis agen biologi Black Soldier Fly (BSF). Kegiatan pengabdian ini bertujuan untuk meningkatkan pengetahhuan dan kesadaran masyarakat untuk melakukan pengelolaan sampah di tingkat desa baik secara mandiri maupun dilakukan oleh pemerintah desa. Pelaksanaan pengabdian dilakukan dalam 4 tahapan yaitu respon awal, penyuluhan, demplot dan evaluasi. Hasil evaluasi pelaksanaan pengabdian menunjukkan perbaikan pemahaman mitra tentang sampah, magot dan pengelolaan sampah menggunakan magot. Namun untuk menjadi pionir dalam pengelolaan sampah, belum ada masyarakat yang bersedia, $13.3 \%$ masih ragu dan $86.6 \%$ belum tidak bersedia.
\end{abstract}

Keywords: Restoran apung, sampah, pengelolaan, swadaya.

tidak terpakai oleh makhluk hidup dan menjadi benda buangan (Amasuomo \& Baird, 2016). Jumlah terbanyak yang dihasilkan adalah sampah organik (Pathiassana et al., 2020). Permasalahan tentang sampah seperti tidak 
pernah berakhir selama kehidupan masih ada. Produksi sampah berbanding lurus dengan bertambahnya industri dan jumlah penduduk (Lesmana, 2017). Semakin banyak jumlah industri dan penduduk, maka sampah yang dihasilkan juga semakin banyak (Widayanti et al., 2017). Pembuangan sampah yang tidak terurus dengan baik akan mengakibat berbagai masalah diantaranya pencemaran tanah, air, udara, saluran air tersumbat serta menjadi sumber penyakit (Hirsan et al., 2021). Permasalahan sampah tidak hanya terjadi di perkotaan yang padat penduduk, tetapi juga terjadi di pedesaan yang memiliki jumlah penduduk kecil, terlebih lagi desa tersebut merupakan desa yang menjadi tujuan wisata (Rahmatillah et al., 2019). Wilayah pesisir selatan Lombok Timur merupakan aset daerah yang sangat potensial untuk dikelola (Sukuryadi \& Ibrahim, 2018), termasuk sebagai daerah tujuan wisata, salah satunya adalah Desa Ekas Buana.

Desa Ekas Buana merupakan salah satu tujuan wisata yang memiliki kekhasan sebagai tujuan wisata berbasis pantai pasir putih dan wisata kuliner tengah laut berupa restoran apung. Kegiatan wisata kuliner ditengah laut berpotensi menimbulkan masalah. Salah satu masalah yang berpotensi muncul adalah cemaran air laut akibat pembuangan sisa makanan dan minyak goreng yang digunakan. Dewilda et al., (2019) menyatakan bahwa restoran merupakan salah satu sumber sampah sisa makanan paling besar. Sementara Azis et al., (2020), menyatakan persentase sampah terbesar di lokasi wisata pesisir adalah sisa makanan. Sisa makanan apabila dibuang langsung ke laut akan menyebabkan terjadinya pencemaran. Permasalahan ini tentunya belum menjadi masalah besar ketika restoran yang beroperasi masih sedikit. Tetapi, seiring dengan bertambahnya jumlah restoran, masalah yang ditimbulkan akan semakin besar dan berpeluang menjadi sumber pencemaran di laut.

Langkah awal yang dilakukan untuk mencegah munculnya permasalahan sampah adalah melalui transfer ilmu pengetahuan.
Ghazali et al., (2021) menyatakan bahwa transfer ilmu pengetahuan yang dilakukan melalui kegiatan penyuluhan bertujuan untuk memperkaya pengetahuan masyarakat. Penyuluhan pengelolaan sampah mampu meningkatkan pengetahuan dan kesadaran masyarakat untuk memilah sampah organic dan anorganik (Trisnawati dan khasanah, 2020). Selain itu, diperlukan pelatihan langsung tentang pengelolaan sampah sehingga masyarakat menjadi lebih faham.

Pengelolaan sampah tidak hanya selesai pada peningkatan pengetahuan saja tetapi lebih pada aksi nyata dalam pengelolaan sampah. Teknologi pengolahan sampah telah banyak dikembangkan di Indonesia. Namun dalam beberapa tahun terakhir telah dikembangkan sistim pengolahan sampah berbasis biokonversi menggunkan BSF (Black Soldier Fly). Lalat ini berasal dari Amerika lalu menyebar ke daerah sub tropis dan tropis (Čičková et al., 2015). Larva hewan ini (magot) memiliki kemampuan mendapatkan energi dan nutrisi dari sisa makanan, sayuran, bangkai, kotoran atau bahan organic lain (Alvarez, 2012; Pathiassana et al., 2020). Hasil penelitian (Putra \& Ariesmayana, (2020) menunjukkan bahwa 100 gr magot dapat mengurai 250 gr sampah organic dalam waktu 7 hari. Magot memiliki kemampuan mendegradasi sampah lebih baik dibandingkan dengan serangga lain (Kim et al., 2011).

Berdasarkan permasalahan yang dihadapi oleh mitra serta peluang pemanfaatan magot sebagai agen biologi pengolahan sampah, maka tim pelaksana pengabdian melakukan kegiatan pengabdian dengan transfer pengetahuan melalui kegiatan sosialisasi dan tranfer teknologi melalui demplot percobaan pengelolaan sampah dengan memanfaatkan agen biologi magot. Tujuan dari kegiatan ini adalah meningkatkan pengetahuan dan kesadaran masyarakat untuk melakukan pengelolaan sampah di tingkat desa baik secara mandiri maupun dilakukan oleh pemerintah desa.

\section{Metode Pelaksanaan Pengabdian}


Pengabdian pada masyarakat ini melibatkan perwakilan dari setiap kelompok masyarakat yang ada di Desa Ekas Buana. Perwakilan kelompok masyarakat terdiri dari unsur pemerintah desa (3 orang), Kepala wilayah (2 orang), Karang taruna (1 orang), Ketua RT (2 orang), Remaja Masjid (1 orang), Bumdes (1 orang), Kelompok pembudidaya rumput laut (1 orang), Kelompok pembudidaya lobster ( 1 orang), pelaku usaha restoran apung (2 orang) dan kelompok sadar wisata (1 orang). Dengan demikian, jumlah peserta pada kegiatan ini sebanyak 15 orang. Adanya kegiatan pengabdian ini diharapkan mampu menginisiasi terbentuknya kerjasama yang baik dari semua kelompok dalam mengelola sampah yang dihasilkan dari kegiatan wisata yang ada di Desa Ekas Buana. Untuk meningkatkan keberhasilan kegiatan keberhasilan, maka kegiatan ini dibagi menjadi tiga tahapan yaitu kuisioner Pra dan Post Test (Nurhayati et al., 2021) dan, Penyuluhan dan demplot percobaan.

\section{Kuisioner Pra Kegiatan}

Penggunaan kuisioner dilakukan untuk mengetahui tingkat pemahaman masyarakat tentang magot. Beberapa pertanyaan yang diajukan antara lain adalah apakah masyarakat tahu bahaya sampah dibuang sembarangan, bagaimana pengelolaan sampah, apakah tahu tentang magot, cara mengolah sampah dengan magot, manfaat magot untuk hewan ternak, apakah mau terlibat dalam pengelolaan sampah dengan magot.

\section{Penyuluhan}

Penyuluhan adalah upaya yang dilakukan untuk transfer ilmu pengetahuan kepada masyarakat (Nurhayati et al., 2021). Kegiatan ini berfungsi meningkatkan pengetahuan masyarakat secara teoritis. Pada kegiatan ini materi penyuluhan yang diberikan adalah materi tentang sampah, bahaya dan pengelolaannya dan materi kedua adalah tentang pemanfaatan magot sebagai agen pengelolaan sampah. Pada kegiatan penyuluhan tim pelaksana kegiatan pengabdian bekerjasama dengan Rumah Magot Lombok sebagai salah satu narasumber.

\section{Demplot Percobaan}

Demplot percobaan dilakukan untuk memberikan pemahaman masyarakat secara langsung bagaimana cara memanfaatkan magot untuk mengelola sampah (Ghazali et al., 2020). Magot untuk demplot percobaan didapatkan dari rumah magot Lombok. Demplot percobaan yang digunakan berupa nampan plastik sebagai wadah untuk tempat penyimpanan sambah. Adapun langkah-langkah yang dilakukan dalam pembuatan demplot adalah sebagai berikut: 1) Menyiapkan nampan sebagai wadah pengolah sampah, 2) menyiapkan sampah yang akan digunakan (ditimbang untuk mengetahui berat awal) untuk demplot yang didapatkan dari sisa makanan restoran apung, 3) menyiapkan magot (ditimbang untuk mengetahui berat awal) sebagai agen pengolah sampah, 4) sampah dan magot ditempatkan ke dalam nampah pengolah sampah, 5) amati pengurangan sampah setiap hari sampai sampah lunak tidak tersisa atau mengering. 6) timbang berat akhir sampah dan magot untuk mengetahui perubahan berat yang terjadi.

4. Evaluasi Kegiatan Pengabdian

Kuisioner pasca kegiatan bertujuan untuk melihat perubahan pemahaman masyarakat atau mitra setelah kegiatan pengabdian selesai (Nurhayati et al., 2021). Selain itu, pada kuisioner ini diberikan tambahan pertanyaan terkait dengan kesediaan atau antusiame menjadi inisiator dalam mengelola sampah mengguakan magot.

\section{Hasil dan Pembahasan}

1. Pemahaman Mitra Terhadap Magot.

Kegiatan pengabdian pada masyarakat diawali dengan melakukan survey sederhana untuk mengetahui pemahaman awal mitra tentang topik pengabdian yang akan dilaksanakan (Gambar 1). Beberapa pertanyaan yang diajukan dan respon masyarakat adalah sebagai berikut.

a. Bahaya sampah

Semua responden yang menjadi peserta memberikan jawaban bahwa mereka faham tentang bahaya yang ditimbulkan sampah yag 
tidak dikelola dengan baik. Beberapa dampak negative sampah menurut responden antara lain: 1) keberadaan sampah merusak pemandangan, terlebih lagi Desa Ekas Buana sedang berbenah dalam pengembangan wisata. 2) menimbulkan bau menyengat, dan 3). mencemari perairan.

b. Magot

Pengetahuan responden tentang magot masih sangat terbatas, hal ini terlihat dari persentase responden yang mengetaui tentang magot masih terbatas. Dari keseluruhan responden yang diminta tanggapannya hanya $20 \%$ yang mengetahui tentang magot. Responden yang faham tetang magot merupakan responden yang merupakan staf pemerintah Desa Ekas Buana. Sementara sebagian besar responden belum mengetahui tentang magot.

c. Pengelolaan sampah menggunakan magot

Penggunaan magot sebagai agen biologi untuk mengolah sampah hanya diketahui oleh $20 \%$ responden, sama seperti pemahaman tentang Magot.

d. Manfaat magot sebagai pakan

Penggunaan magot sebagai pakan hewan ternak (ayam/burung/ikan) hanya diketahui oleh $10 \%$ responden. Menurut keterangan responden, penggunaan magot sebagai pakan ia ketahui dari sahabatnya yang hobi memelihara burung. Dimana burung peliharaan tersebut diberi makan menggunakan magot.

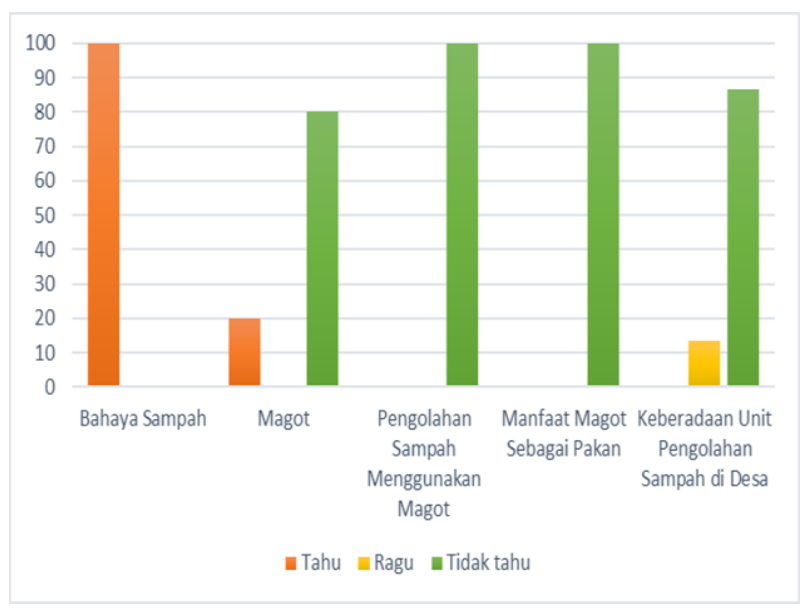

Gambar 1. Grafik pemahaman mitra sebelum pelaksanaan pengabdian tentang sampah, magot dan peran magot sebagai agen pengolah sampah.

e. Keberadaan Unit Pengelola Sampah di Desa Ekas Buana

Pertanyaan terakhir yang diajukan kepada responden adalah tentang keberadaan unit pengolahan sampah di Desa Ekas Buana. $13.3 \%$ responden mengatakan keraguan tentang keberadaan unit pengolahan sampah, sementara $86.7 \%$ responden mengatakan tidak ada atau belum ada unit pengolahan sampah di Desa tersebut.

2. Sosialisasi Peranan Magot Dalam

Pengelolaan Sampah Organik Berkelanjutan.

Sosialisasi peranan magot (Gambar 2) sebagai agen biologi dalam pengelolaan sampah dilakukan setelah mendapatkan pemahaman awal mitra melalui kuisioner yang diberikan diawal kegiatan. Materi sosialisasi yang diberikan terdiri dari 3 topik utama yaitu: 1) Wisata, sampah dan penanganannya, 2). Magot sebagai agen biologi pengelolaan sampah berkelanjutan dan 3). Teknik penangkapan inang magot.

Materi terkait dengan pengelolaan sampah yang berasal dari kegiatan usaha restoran apung diberikan sebagai upaya untuk mengurangi pencemaran akibat sisa makanan, terutama yang mengandung minyak. Berdasarkan hasil pemantauan, ditemukan pengelola masih mebuang sisa makanan terutama yang mengandung minyak, seperti sisa sambal, sisa makanan dan minyak yang masih menempel di piring. Oleh sebab itu, pada sosialisasi pertama ditekankan tentang bahayanya dan peluang penurunan wisatawan ketika perairan menjadi tercemar. Sebagian besar wisatwan yang berkunjung tidak hanya fokus pada wisata kuliner, tetapi juga berwisata main air, termasuk mandi dan snorkling. Oleh sebab itu, perairan harus bebas sampah dan minyak.

Materi kedua yang disampaikan pada kegiatan sosialisasi adalah pengelolaan sampah berkelanjutan menggunakan magot. Materi 
yang disampaikan terkait dengan pengelolaan sampah harus dimulai dari skala paling kecil yaitu rumah tangga, warung, restoran dll. Sampah dapat dipilih berdasarkan jenisnya yaitu sampah organik dan anorganik. Pemilahan sampah berfungsi memudahkan dalam pemilihan untuk diolah atau dikirim ke tempah pengolahan sampah anorganik. Selanjutnya disampaikan juga bahwa pengolahan sampah organik dapat dilakukan pada skala rumah tangga dengan memanfaatkan magot sebagai agen pengolah. Magot merupakan organisme yang berasal dari lalat Black Soldier Fly (BSF). Magot atau belatung merupakan agen biologi yang dapat digunakan sebagai agen untuk mengolah sampah organik, sebagai upaya untuk menghindari terjadinya permasalahan akibat penumpukan sampah. Budidaya magot dapat memberikan manfaat ekonomi bagi masyaraka, serta mengdukasi masyarakat untuk melakukan pemilahan sampah sejak dari sumbernya.

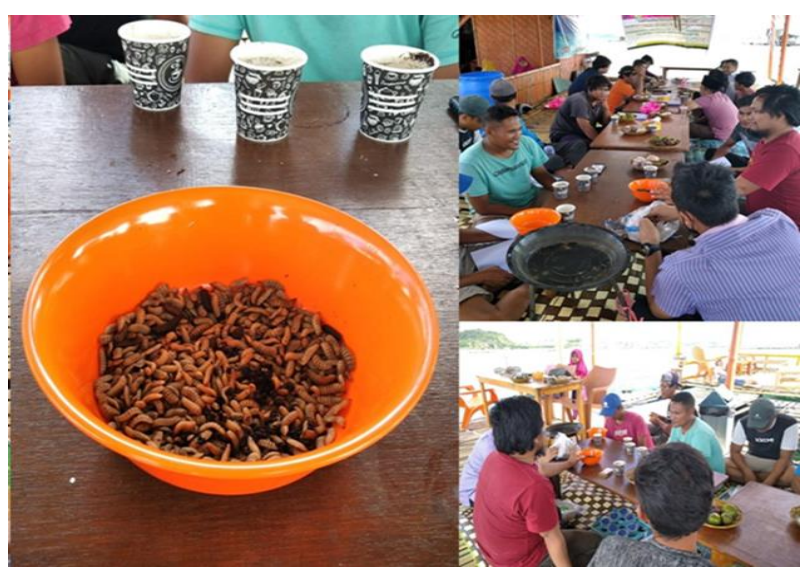

Gambar 2. Kegiatan sosialisasi pengelolaan sampang menggunakan magot

Materi terakhir yang disampaikan adalah metode penangkapan inang magot. Pada materi yang ke-3 ini dijelaskan tentang tatacara untuk mendapatkan magot untuk pertama kalinya. Artinya bahwa ketika masyarakat ingin melakukan pengelolaan sampah menggunkan magot, maka masyarakat tidak harus membeli telur magot. Alur penangkapan magot yang dijelaskan antara lain adalah:

a. Penyiapan media pemancingan alat BSF
Media yang digunakan merupakan media sederhana yang dapat ditemukan dengan mudah. Bahan-bahan yang digunakan antara lain dedak $5 \mathrm{~kg}$, yakult 1 botol, gula pasir 2.5 sendok teh, royko setengah saset, dan air 1 liter. Semua bahan dicampukan menjadi 1 dan diaduk rata. Adonan yang bagus adalah adonan yang apabila digenggam tidak meneteskan air dan bila dilepas adonan tidak hancur. Adonan kemudian dimasukkan kedalam kantong plastik untuk difermentasi selama 4-5 hari. Keberhasilan fermentasi dilihat dari terbentuknya gas yang dapat diamati dari kantong plastik yang semakin mengembang.

b. Langkah penangkapan magot.

Hasil fermentasi media penangkapan kemudian ditempat pada wadah plastik, kemudian ditutup dengan daun pisang. Pada langkah ini dijelaskan pula bahwa wadah plastik ditempatkan pada area kandang atau tempat sampah tetapi harus dihindarkan dari ayam atau hewan lain yang tertarik dengan media penangkapan. Untuk memastikan sudah ada atau tidak magot pada media penangkapan, maka wadah ahrus diperiksa setiap 2-3 hari. Pada umumnya magot akan ditemukan pada kisaran 10-14 hari.

3. Demplot Percobaan Penggunaan Magot untuk Pengolahan Sisa Makanan Warung Apung

Demplot percobaan dilakukan untuk memberikan pemahaman kepada mitra tentang proses pengolahan sampah menggunakan magot. Sampah yang digunakan pada demplot percobaan ini adalah sampah sisa makanan tamu yang berkunjung ke restoran apung Orange Caramba "Despita". Restoran ini merupakan salah satu restoran yang beroperasi di teluk ekas dan mejadi salah satu mitra pada kegiatan pengabdian ini. Adapun Langkah yang dilakukan pada demplot percobaan ini adalah:

a. Pengumpulan sampah sisa makanan

Sampah sisa makanan dari berbagai jenis ikan, kepiting, nasi dikumpulkan menjadi satu dalam wadah plastik (Gambar 3). Hasil yang didapatkan kemudian ditimbang untuk 
mengetahui berat awal. Data berat awal yang didapatkan sebanyak $1.6 \mathrm{~kg}$.

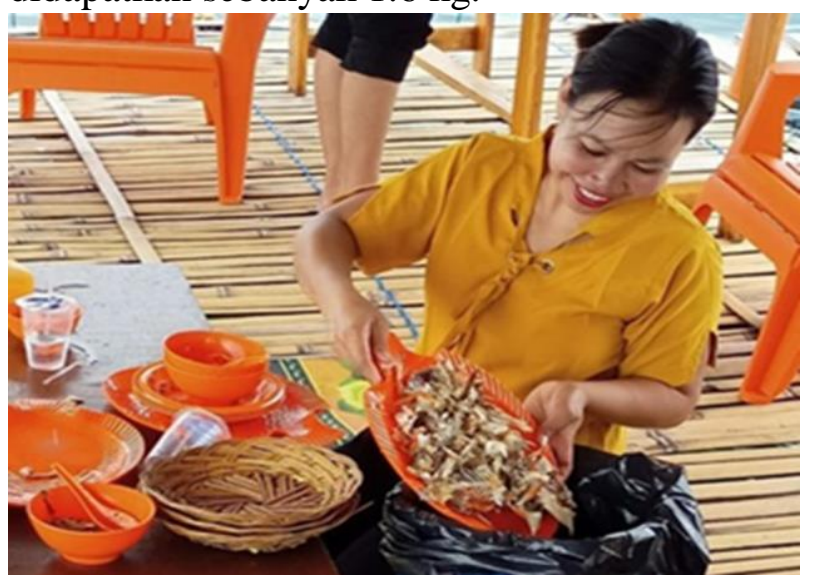

Gambar 3. Pengumpulan sampah sisa makanan dari restoran apung orange caramba "Despita". b. Penimbangan magot

Pada kegiatan pengabdian ini,fase hidup yang digunakan adalah larva magot (tidak menggunakan telur). Hal ini bertujuan untuk melihat kecepatan dekomposisi sampah sisa makanan, sehingga waktu yang dibutuhkan lebih singkat. Berat magot yang digunakan adalah sebanyak $1 \mathrm{~kg}$.

c. Aplikasi magot pada sampah sisa makanan

Magot yang telah ditimbang kemudian dicampurkan atau dilepaskan ke dalam sampah sisa makanan yang telah ditempatkan dalam wadah plastik (Gambar 4).

d. Pengamatan hasil akhir

Aplikasi magot pada sampah sisa makanan diamati setiap 12 jam. Hasil pengamatan menunjukkan wahwa dalam waktu 36 jam terjadi pengurangan sampah sebesar 1,244 $\mathrm{kg}$ atau tersisa sebanyak 0.356 $\mathrm{Kg}$. Sementara berat magot meningkat menjadi $1.5 \mathrm{~kg}$.

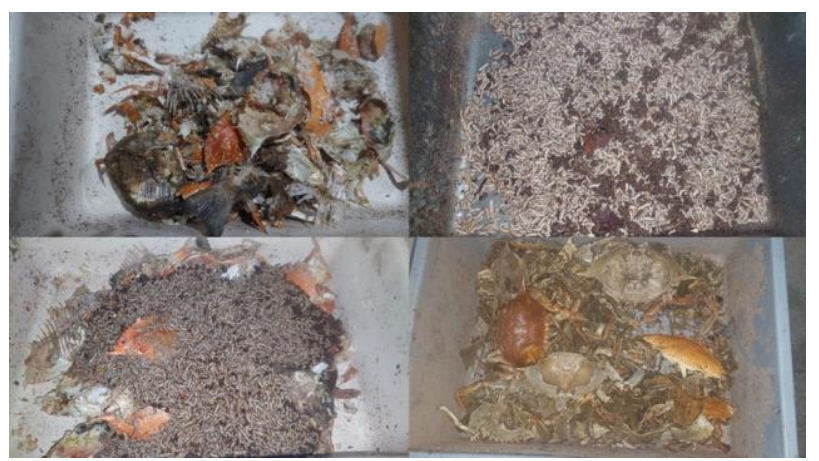

Gambar 4. Proses pengolahan sampah menggunakan magot

Hasil pengolahan sampah dengan memanfaatkan larva magot menunjukkan laju dekomposisi sampah tergolong cepat. Namun demikian masih terdapat sisa sampah yang belum terdekomposisi. Salah satu penyebabnya adalah sampah sisa merupakan tulang dan cangkang kepiting yang memiliki tekstur keras. Dekomposisi sampah tulang dan cang memerlukan perlakuan awal dengan menggilingnya sehingga mudah didekomposisi atau jika tidak terdekompoisi, maka padatan sisa dapat digunakan sebagai pupuk organic padat untuk media tanam.

4. Perubahan pemahaman Mitra pascaKegiatan Pengabdian.

Pengukuran keberhasilan kegiatan pengabdian salah satunya dilihat dari perubahan persepsi peserta setelah kegiatan selesai. Perubahan persepsi mitra dilihat dengan melakukan survei kembali dengan mengajukan pertanyaan yang sama. Selain itu, pertanyaan yang diajukan dalam survei ditambah dengan peluang mitra/peserta kegiatan untuk melakukan kegiatan pengolahan sampah menggunakan magot. Berdasarkan survei yang pasca kegiatan yang dilakukan didapatkan data perubahan persepsi mitra (Gambar).

Hasil evaluasi pelaksanaan pengabdian menunjukkan perbaikan pemahaman mitra tentang sampah, magot dan pengelolaan sampah menggunakan magot. Namun dari hasil evaluasi didapatkan hasil yang menarik terkait komitmen keikutsertaan dalam Pengelolaan sampah menggunakan magot. Tiga belas persen peserta menyatakan ragu untuk terlibat dalam pengelolaan sampah. Alasan utama keraguan adalah permodalan, sistem pengumpulan sampah, lokasi dan penjualan larva magot sebagai pakan ternak. Sementara delapan puluh tujuh persen menyatakan tidak bersedia. Alasan utamanya adalah secara ekonomi terlihat masih belum menguntungkan. Sementara itu, tidak satupun peserta yang 
berkomitmen untuk menjadi pionir dalam pengelolaan sampah menggunakan magot.

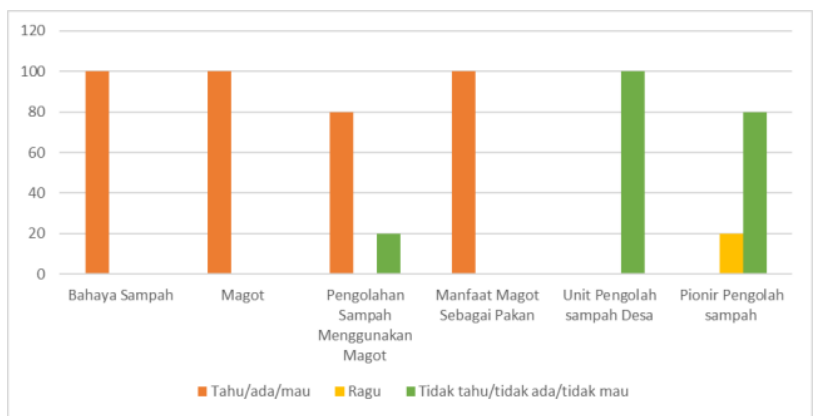

Gambar 5. Perubahan persepsi peserta kegiatan pengabdian

\section{Kesimpulan}

Berdasarkan kegiatan yang telah dilakukan maka dapat disimpulkan bahwa kegiatan ini memiliki dampak terhadap peningkatan pemahaman mitra tentang magot, manfaat magot sebagai pakan dan peranan magot sebagai agen biologi dalam pengelolaan sampah. Selain itu, dari kegiatan ini belum ada mitra yang siap sebagai pionir dalam pengelolaan sampah dengan berbagai alasan.

\section{Saran}

Untuk mendorong munculnya unit pengelolaan sampah diperlukan upaya pendampingan.

\section{Ucapan Terima Kasih}

Ucapan terima kasih disampaikan kepada, Direktorat Riset dan Pengabdian Masyarakat Direktorat Jenderal Riset dan Pengembangan, Kementerian Riset, Teknologi dan Pendidikan Tinggi, LPPM Universitas Muhammadiyah Mataram, Pemerintah Desa Ekas Buana, Kepala Wilayah, Mitra PKM, Rumah Magot Lombok serta semua pihak yang telah mendukung terlaksananya kegiatan ini

\section{Daftar Pustaka}

Alvarez, L. (2012). The Role of Black Soldier Fly, Hermetia illucens (L.) (Diptera: Stratiomyidae) in Sustainable Waste Management in Northern Climates.
Electronic Theses and Dissertations. https://scholar.uwindsor.ca/etd/402

Amasuomo, E., \& Baird, J. (2016). The Concept of Waste and Waste Management. Journal of Management and Sustainability, 6(4), 88. https://doi.org/10.5539/jms.v6n4p88

Azis, R., Akolo, I. R., Pomalingo, Moh. F., \& Staddal, I. (2020). Pengembangan Usaha Minyak Kelapa Tradisional untuk Meningkatkan Pendapatan IKM Desa Posso, Kabupaten Gorontalo Utara. Agrokreatif: Jurnal Ilmiah Pengabdian kepada Masyarakat, 6(2), 150-158.

https://doi.org/10.29244/agrokreatif.6.2. 150-158

Čičková, H., Newton, G. L., Lacy, R. C., \& Kozánek, M. (2015). The use of fly larvae for organic waste treatment. Waste Management (New York, N.Y.), 35 , 68-80. https://doi.org/10.1016/j.wasman.2014. 09.026

Dewilda, Y., Aziz, R., \& Fauzi, Mhd. (2019). Kajian Potensi Daur Ulang Sampah Makanan Restoran di Kota Padang. Jurnal Serambi Engineering, 4(2). https://doi.org/10.32672/jse.v4i2.1325

Ghazali, M., Kurnianingsih, R., Nurhayati, N., \& Sunarpi, S. (2020). PENDAMPINGAN KELOMPOK TANI "PASIR PUTIH" DALAM MEWUJUDKAN DESA EKAS BUANA SEBAGAI LUMBUNG BIBIT RUMPUT LAUT NUSA TENGGARA BARAT. JMM (Jurnal Masyarakat Mandiri), 4(5), 742-751. https://doi.org/10.31764/jmm.v4i5.2950 Ghazali, M., Rabbani, R., Sari, M., Rohman, M. H., Nasiruddin, M. H., Suherman, S., \& Nurhayati, N. (2021). Pelatihan Pengolahan Kerupuk Ikan di Desa Ekas Buana Kecamatan Jerowaru Kabupaten Lombok Timur. Jurnal Pengabdian Magister Pendidikan IPA, 4(2), Article 
2.

https://doi.org/10.29303/jpmpi.v4i2.683

Hirsan, F. P., Susanti, F., \& Ridha, R. (2021). Analisis Hubungan Perubahan Penggunaan Lahan Untuk Komoditas Jagung dan Degradasi Lingkungan di Kabupaten Dompu Fariz Primadi Hirsan, Febrita Susanti, Rasyid Ridha. PROSIDING SEMINAR NASIONAL PLANOEARTH, 2, 42-47.

Kim, W., Bae, S., Park, K., Lee, S., Choi, Y., Han, S., \& Koh, Y. (2011). Biochemical characterization of digestive enzymes in the black soldier fly, Hermetia illucens (Diptera: Stratiomyidae). Journal of Asia-Pacific Entomology, 14(1), 11-14. https://doi.org/10.1016/j.aspen.2010.11. 003

Lesmana, R. Y. (2017). Estimasi Laju Timbulan Sampah dan Kebutuhan Landfill Periode 2018-2027 (Studi Kasus Kec. Mentawa Baru Ketapang, Kab. Kotawaringin Timur, Kalimantan Tengah). Media Ilmiah Teknik Lingkungan, 2(2), 20-24. https://doi.org/10.33084/mitl.v2i2.124

Nurhayati, N., Ihromi, S., Asmawati, A., Marianah, M., Saputrayadi, A., \& Jahidin, M. (2021). PELATIHAN PEMBUATAN TEH KELOR SEBAGAI UPAYA MENJAGA IMUNITAS TUBUH SELAMA MASA PANDEMI COVID-19. SELAPARANG Jurnal Pengabdian Masyarakat Berkemajuan, 4(2), 477-482. https://doi.org/10.31764/jpmb.v4i2.465 9

Nurhayati, N., Ihromi, S., \& Sari, D. A. (2021). PELATIHAN PENGOLAHAN SIRUP, SELAI, DAN ABON BERBASIS NANAS. Jurnal Agro Dedikasi Masyarakat (JADM), 2(1), 15-21.

Nurhayati, N., Sulastri, Y., Ghazali, M., \& Ibrahim, I. (2021). PENYULUHAN CARA PENGOLAHAN PANGAN YANG BAIK UNTUK PERBAIKAN
PROSES PRODUKSI DAN MUTU MINYAK KELAPA DI IKM SAKRA TIMUR LOMBOK. JMM (Jurnal Masyarakat Mandiri), 5(1), 152-160. https://doi.org/10.31764/jmm.v5i1.3502

Pathiassana, M. T., Izzy, S. N., \& Nealma, S. (2020). STUDI LAJU UMPAN PADA PROSES BIOKONVERSI DENGAN VARIASI JENIS SAMPAH YANG DIKELOLA PT. BIOMAGG SINERGI INTERNASIONAL

MENGGUNAKAN LARVA BLACK SOLDIER. Science and Technology, 4(1), 10.

Putra, Y., \& Ariesmayana, A. (2020). EFEKTIFITAS PENGURAIAN SAMPAH ORGANIK MENGGUNAKAN MAGGOT (BSF) DI PASAR RAU. 3(1), 14.

Rahmatillah, T. P., Insyan, O., Nurafifah, N., \& Hirsan, F. P. (2019). Strategi Pengembangan Desa Wisata Berbasis Wisata Alam dan Budaya Sebagai Media Promosi Desa Sangiang Tri Putri Rahmatillah1, Osy Insyan1, Nurafifah2, Fariz Primadi Hirsan. Jurnal Planoearth, 4(2), 111-116.

Sukuryadi, \& Ibrahim. (2018). PEMETAAN POTENSI SUMBERDAYA WILAYAH PESISIR SELATAN KABUPATEN LOMBOK TIMUR DENGAN APLIKASI SISTEM INFORMASI GEOGRAFIS. Paedagoria: Jurnal Kajian, Penelitian Dan Pengembangan Kependidikan, 6(1), 37-48.

Widayanti, B. H., Hirsan, F. P., \& Kurniawan, A. (2017). Effectiveness of waste management in Mataram City. IOP Conference Series: Earth and Environmental Science, 70, 012004. https://doi.org/10.1088/17551315/70/1/012004 